\title{
PCR-RFLP analysis of rbcL chloroplast gene
}

\author{
Olga Sheikina* \\ Volga State University of Technology, Forestry Department, 424000, 3, Lenin Square, Yoshkar-Ola, \\ Republic of Mari El, Russian Federation
}

\begin{abstract}
To identify intergeneric, interspecific, and intraspecific polymorphisms, PCR-RFLP studies of the chloroplast rbcL gene profiles were carried out using five restriction endonucleases (AluI, HpaII, BsuRI, BstHHI, BstMBI) in 14 species belonging to 6 different genera and 7 Thuja occidentalis cultivars. For all the genera studied (Pinus sp., Abies sp., Picea sp., Microbiota sp., Syringa sp., Thuja sp.), A genus-specific restriction profile characterized by a unique combination of restriction DNA fragments was revealed. The combination of enzymes used in the study did not reveal the interspecies and intraspecific variability of the rbcL gene. Species belonging to the same genus and all varieties of western thuja were characterized by identical PCR-RFLP profiles. It is assumed that further research, with the inclusion of a larger number of species and enzymes, will reveal polymorphism at the interspecies and intraspecific levels.
\end{abstract}

\section{Introduction}

PCR-RFLP analysis (Polymerase Chain Reaction - Restriction Fragment Length Polymorphism) of chloroplast DNA (chlDNA) is widely used for phylogenetic studies, especially at the interspecies level and above [1-3]. The highly conservative nature of the chloroplast genome makes it possible to create universal primers for amplification of the target DNA region, which makes it possible to compare the sequence of many species [4]. To date, studies of interspecies polymorphism have been carried out using restriction analysis of amplified chloroplast DNA from different species of the Pinaceae family [1] and different species of the genus Abies [2]. In a number of studies, it was possible to detect intraspecific variability of different parts of the chloroplast genome $[2,5]$. On the other hand, not all restriction endonucleases make it possible to establish differences in the nucleotide sequences of chlDNA [6]. Therefore, research is needed to search for restriction enzymes that allow detecting polymorphism at various levels - intraspecific, interspecific and intergeneric.

Quite often, the $r b c L$ chloroplast gene is chosen as the object of PCR-RFLP analysis. The $r b c L$ gene encodes a large subunit of the ribulose-1,5-bisphosphate carboxylase enzyme. Identification of polymorphism in the $r b c L$ gene is an important scientific task, since this sequence has a low mutation level compared to other regions in cIDNA, and a high level of similarity between species [7].

\footnotetext{
* Corresponding author: ShejkinaOV@volgatech.net
} 
The aim of the study was to identify the nucleotide polymorphism of the chloroplast rbcL gene at the generic, interspecific and intraspecific levels using PCR-RFLP analysis. Achievement of this goal provided for the solution of the following tasks: 1) collection of plant material and analysis using five recession endonucleases; 2) comparative analysis of restriction profiles of representatives of different families, genera and species of woody plants; 3) comparative analysis of restriction profiles of thuja european varieties to identify intraspecific polymorphism of the rbcL gene.

\section{Methods}

\subsection{Plant material and DNA extraction}

The needles and leaves were collected from 21 trees growing in the collection of the Botanical Garden-Institute of the Volga State Technological University (Russia, Middle Volga region, Yoshkar-Ola). The studies included 14 different species of the three genera Pinaceae, Cupressaceae and Oleaceae (Table 1). To assess the intraspecific variability of the rbcL gene, the study included 7 varieties of western thuja (Thuja occidentalis): 'Cristata', 'Douglasii Pyramidalis', 'Ellwangeriana Aurea', 'Ericoides', 'Globosa', 'Danica', 'Aurea'. DNA was extracted from needles and leaves using the CTAB method [8].

Table 1. Characteristics of taxa used in the study.

\begin{tabular}{|c|c|c|c|}
\hline & species & Family & Range of the species \\
\hline 1 & Pinus peuce Griseb. (1846) & Pinaceae & $\begin{array}{l}\text { Mountain regions of southern and } \\
\text { eastern Europe }\end{array}$ \\
\hline 2 & Pinus radiata D.Don (1836) & Pinaceae & $\begin{array}{c}\text { Central coast of California and } \\
\text { Mexico }\end{array}$ \\
\hline 3 & Pinus strobus L. (1753) & Pinaceae & US Northeast, Canada Southeast \\
\hline 4 & Abies sibirica Ledeb. (1833) & Pinaceae & $\begin{array}{l}\text { North-East of the European part of } \\
\text { Russia, the Urals, Western and } \\
\text { Eastern Siberia, the north of } \\
\text { Mongolia and China. }\end{array}$ \\
\hline 5 & Abies fraseri (Pursh) Poir. (1817) & Pinaceae & $\begin{array}{l}\text { Southeast Appalachian Mountains } \\
\text { (North America) }\end{array}$ \\
\hline 6 & $\begin{array}{l}\text { Picea mariana (Mill.) Britton, } \\
\text { Sterns \& Poggenb. (1888) }\end{array}$ & Pinaceae & Northern USA \\
\hline 7 & Picea asperata Mast. (1906) & Pinaceae & China \\
\hline 8 & $\begin{array}{c}\text { Picea alcoquiana (H.J.Veitch ex } \\
\text { Lindl.) Carriere (1867) }\end{array}$ & Pinaceae & Japan \\
\hline 9 & $\begin{array}{c}\text { Thuja plicata Donn ex D.Don } \\
(1824)\end{array}$ & Cupressaceae & Northwest North America \\
\hline 10 & Thuja occidentalis L. (1753) & Cupressaceae & $\begin{array}{l}\text { Southeast Canada, northern United } \\
\text { States }\end{array}$ \\
\hline 11 & Thuja koraiensis Nakai (1919) & Cupressaceae & Korea, China \\
\hline 12 & Microbiota decussata Kom. (1923) & Cupressaceae & Russian Far East \\
\hline 13 & $\begin{array}{c}\text { Syringa komarowii C.K. Schneid } \\
(1910)\end{array}$ & Oleaceae & Central China \\
\hline 14 & Syringa amurensis Rupr. (1857) & Oleaceae & $\begin{array}{c}\text { Far East of Russia, North-East of } \\
\text { China }\end{array}$ \\
\hline
\end{tabular}




\subsection{PCR-RFLP analysis}

PCR was performed using specific primers for the $r b c L$ gene: rbcL1F 5'ATGTCACCACAAACAGAAACTAAAGC-3' and rbcL1352R 5'CTTCACAAGCAGCAGCTAGTTC-3'). The reaction in a total volume of $50 \mu$ l contained $5 \mu \mathrm{l}$ of buffer, $3 \mu \mathrm{l}$ of DNA template, $0.8 \mu \mathrm{l}$ of each primer, $0.8 \mu \mathrm{l}$ of dNTPs mixture, $0.8 \mu \mathrm{l}$ of Tag polymerase enzyme, and $39.6 \mu \mathrm{l}$ of sterile water. Amplification conditions: preliminary denaturation at $95^{\circ} \mathrm{C}$ for 5 minutes; 45 cycles of amplification, including denaturation of $45 \mathrm{sec}$. at $95^{\circ} \mathrm{C}$, primer annealing $45 \mathrm{sec}$. at $60^{\circ} \mathrm{C}$ and elongation $90 \mathrm{sec}$. at $72^{\circ} \mathrm{C}$; final elongation at $72^{\circ} \mathrm{C}$ for 10 minutes. PCR was performed using a commercial Encyclo Plus PCR kit (Evrogen) in an MJ MiniTM Gradient Thermal Cycler (Bio-Rad).

DNA amplicons were sequentially treated with five restriction endonucleases at $37^{\circ} \mathrm{C}$ for AluI (AG $\downarrow \mathrm{CT})$, HpaII (C $\downarrow$ CGG) and BsuRI (GG $\downarrow \mathrm{CC}), 50^{\circ} \mathrm{C}$ for BstHHI (GCG $\downarrow$ C) and $65^{\circ} \mathrm{C}$ for BstMBI ( $\downarrow$ GATC). The reaction mixture with a total volume of $20 \mu \mathrm{l}$ contained the following components: PCR product - $7 \mu \mathrm{l}$, buffer $-2 \mu \mathrm{l}$, enzyme $-0.5 \mu \mathrm{l}$, sterile water $10.5 \mu \mathrm{l}$. Digested PCR products were separated using $1.5 \%$ agarose gel electrophoresis in $1 \times$ TBE buffer ( $89 \mathrm{mM}$ Tris-borate, $2 \mathrm{mM}$ EDTA, $\mathrm{pH} 8.0)$ and visualized in UV light using the GelDoc 2000 gel documenting system (Bio-Rad ). The length of the restriction fragments was determined using the Quantity One ${ }^{\circledR}$ Version 4.6.3 software compared to the $100+$ bp DNA Ladder (Evrogen).

\section{Results}

For all studied samples, a PCR product of about 1400 base pairs in length was obtained. Sequential processing of the PCR product showed the presence of restriction sites for all five restriction endonucleases used in the work. Figure 1 shows examples of electrophoregrams obtained by electrophoresis of restriction products with BsuRI (A) and AluI (B) enzymes for different tree species. The presence of DNA fragments of different lengths indicates the variability of the location of restriction sites in PCR products of different tree species. Changes in the location of restriction sites are due to the presence of mutations in the gene under study. So, as a result of the replacement of one nucleotide with another, restriction sites can be formed in new regions of the gene, or vice versa, disappear. Mutations such as insertions - insertion of nucleotides into the DNA sequence, and deletions - loss of nucleotides also lead to a change in the length of restriction fragments.

Comparative analysis of the lengths of restriction fragments obtained with the BsuRI enzyme showed the presence of GG $\downarrow$ CC restriction sites in all studied species (Figure 1). At the same time, the number and length of fragments for species belonging to the same genus were identical. For example, in all representatives of the genus Pinus (Pinus peuce Griseb., Pinus radiate D. Don, Pinus strobus L.) three fragments 530, 480, and $390 \mathrm{bp}$ in length were observed upon digestion with the BsuRI enzyme. Therefore, the restriction site GG $\downarrow \mathrm{CC}$, recognized by this restriction enzyme, occurs twice in the rbcL gene. In two species of lilac, Syringa komarowii C.K. Schneid and Syringa amurensis Rupr. three fragments are also observed, but their length was 500, 440, and 400 base pairs. Three fragments were present in the electrophoretogram of the fir Abies sibirica Ledeb. and Abies fraseri (Pursh) Poir. (800, 350 and 200 base pairs long) and in Picea mariana (Mill.) Britton, Sterns \& Poggenb., Picea asperata Mast. and Picea alcoquiana (H. J. Veitch ex Lindl.) Carriere (500, 350 and 250 bp lengths). Microbiota decussata Kom. 4 DNA fragments were detected, the length of which was 500, 440, 400 and 300 base pairs. 


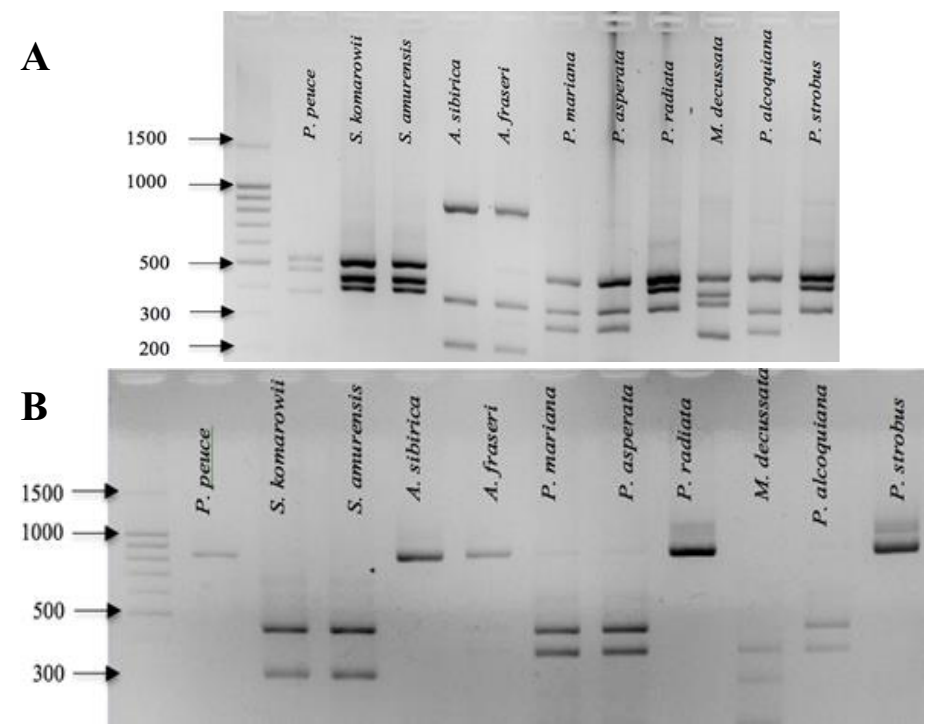

Fig 1. PCR-RFLP profiles of the rbcL gene of different tree species obtained using the enzymes BsuRI (A) and AluI (B).

The genera studied also differed in the location of the AG $\downarrow$ CT restriction site recognized by the AluI enzyme. In all pine species (Pinus peuce Griseb., Pinus radiate D. Don, Pinus strobus L.) and fir (Abies sibirica Ledeb. and Abies fraseri (Pursh) Poir.), Only one DNA fragment with a length of $840 \mathrm{bp}$ was present on the profile (figure 1) For all other species, the presence of two fragments on the electophoregram is characteristic. The fragment lengths for lilac (Syringa komarowii CK Schneid and Syringa amurensis Rupr.) Were 440 and 300 base pairs, for spruce (Picea mariana (Mill.) Britton, Sterns \& Poggenb., Picea asperata Mast. and Picea alcoquiana (HJVeitch ex L .) Carriere) - 440 and 360 base pairs, for microbiota (Microbiota decussata Kom.) - 360 and 300 base pairs.

Characterization of PCR-RFLP profiles of the studied species for all enzymes is presented in Table 2 .

Table 2. Characterization of PCR-RFLP profiles of plants of the genus Pinus, Abies, Picea, Microbiota and Syringa.

\begin{tabular}{|c|c|c|c|c|c|}
\hline \multirow[t]{2}{*}{ species } & \multicolumn{5}{|c|}{$\begin{array}{l}\text { List of the sizes of fragments formed during processing by } \\
\text { different enzymes, nucleotide pairs }\end{array}$} \\
\hline & BsuRI & AluI & HpaII & BstHHI & BstMBI \\
\hline $\begin{array}{l}\text { Pinus peuce Griseb. } \\
\text { (1846) }\end{array}$ & $530,480,390$ & 840 & $\begin{array}{l}780,380 \\
200\end{array}$ & $\begin{array}{l}650,520 \\
320\end{array}$ & 750,250 \\
\hline $\begin{array}{l}\text { Pinus radiata D.Don } \\
\text { (1836) }\end{array}$ & $530,480,390$ & 840 & $\begin{array}{l}780,380 \\
200\end{array}$ & $\begin{array}{l}650,520 \\
320\end{array}$ & 750,250 \\
\hline $\begin{array}{l}\text { Pinus strobus } L . \\
\text { (1753) }\end{array}$ & $530,480,390$ & 840 & $\begin{array}{l}780,380 \\
200\end{array}$ & $\begin{array}{l}650,520, \\
320\end{array}$ & 750,250 \\
\hline $\begin{array}{l}\text { Abies sibirica Ledeb. } \\
\text { (1833) }\end{array}$ & $800,350,200$ & 840 & $\begin{array}{l}780,400 \\
250\end{array}$ & $\begin{array}{l}650,520, \\
320,280\end{array}$ & $\begin{array}{l}450,360 \\
250\end{array}$ \\
\hline $\begin{array}{l}\text { Abies fraseri (Pursh) } \\
\text { Poir. (1817) }\end{array}$ & $800,350,200$ & 840 & $\begin{array}{c}780,400, \\
250\end{array}$ & $\begin{array}{l}650,520, \\
320,280\end{array}$ & $\begin{array}{c}450,360 \\
250\end{array}$ \\
\hline $\begin{array}{l}\text { Picea mariana (Mill.) } \\
\text { Britton, Sterns \& } \\
\text { Poggenb. (1888) }\end{array}$ & $500,350,250$ & $\begin{array}{l}440 \\
360\end{array}$ & $\begin{array}{l}780,400 \\
250\end{array}$ & $\begin{array}{l}650,520 \\
320\end{array}$ & $\begin{array}{l}450,360 \\
250\end{array}$ \\
\hline
\end{tabular}




\begin{tabular}{lccccc}
\hline $\begin{array}{l}\text { Picea asperata Mast. } \\
\text { (1906) }\end{array}$ & $500,350,250$ & $\begin{array}{c}440, \\
360\end{array}$ & $\begin{array}{c}780,400, \\
250\end{array}$ & $\begin{array}{c}650,520, \\
320\end{array}$ & $\begin{array}{c}450,360, \\
250\end{array}$ \\
\hline $\begin{array}{l}\text { Picea alcoquiana } \\
\text { (H.J.Veitch ex Lindl.) }\end{array}$ & $500,350,250$ & $\begin{array}{c}440, \\
360\end{array}$ & $\begin{array}{c}780,400, \\
250\end{array}$ & $\begin{array}{c}650,520, \\
320\end{array}$ & $\begin{array}{c}450,360, \\
250\end{array}$ \\
$\begin{array}{l}\text { Carriere (1867) } \\
\begin{array}{l}\text { Microbiota decussata } \\
\text { Kom. (1923) }\end{array}\end{array} \begin{array}{c}500,440,400, \\
300\end{array}$ & $\begin{array}{c}360, \\
300\end{array}$ & $\begin{array}{c}1000,300, \\
250\end{array}$ & $\begin{array}{c}650,480, \\
320,280\end{array}$ & 360,230 \\
\hline $\begin{array}{l}\text { Syringa komarowii } \\
\text { C.K. Schneid (1910) }\end{array}$ & $500,440,400$ & $\begin{array}{c}440, \\
300\end{array}$ & 1400 & 1000,350 & 230,200 \\
\hline $\begin{array}{l}\text { Syringa amurensis } \\
\text { Rupr. (1857) }\end{array}$ & $500,440,400$ & $\begin{array}{c}440, \\
300\end{array}$ & 1400 & 1000,350 & 230,200 \\
\hline
\end{tabular}

Frequency of HpaII restriction sites in all fir (Abies sibirica Ledeb. and Abies fraseri (Pursh) Poir.) and spruce (Picea mariana (Mill.) Britton, Sterns \& Poggenb., Picea asperata Mast. and Picea alcoquiana (HJVeitch ex Lindl.) Carriere) turned out to be the same. All types of fir and spruce are characterized by the occurrence of fragments with a length of 780, 400, and 250 base pairs. Three pine species (Pinus peuce Griseb., Pinus radiate D. Don, Pinus strobus L.) showed a slightly different PCR-RFLP profile for this enzyme - 780, 380, and $200 \mathrm{bp}$. In microbiota (Microbiota decussata Kom.), Two restriction sites and three DNA fragments were also found on gels 1000, 300, and 250 base pairs long. The rbcL gene of lilacs (Syringa komarowii C.K. Schneid and Syringa amurensis Rupr.) Did not contain a restriction site for the HpaII enzyme.

The largest number of fragments after treatment with the restriction endonuclease BstHHI was found in fir and microbiota. At the same time, the PCR-RFLP profiles in these species differed only in the length of one fragment: in Abies sibirica Ledeb. and Abies fraseri (Pursh) Poir. the length of the fragments was 650, 520, 320, $280 \mathrm{bp}$, while in Microbiota decussata Kom. - 650, 480, 320, 280 base pairs. For all species of pine and spruce, the same restriction profile was revealed, including fragments of 650, 520, 320 base pairs in length. Restriction profile of Syringa komarowii C.K. Schneid and Syringa amurensis Rupr. is represented by two fragments - 1000 and 350 base pairs.

When the PCR product was cleaved with the BstMBI enzyme, either 2 or 3 DNA fragments were observed in the studied species. Identical fragments of length 450, 360, 250 base pairs. found in fir (Abies sibirica Ledeb. and Abies fraseri (Pursh) Poir.) and spruces (Picea mariana (Mill.) Britton, Sterns \& Poggenb., Picea asperata Mast. and Picea alcoquiana (H. J. Veitch ex Lindl.) Carriere). In other species, 2 fragments were identified: 750 and 250 base pairs in pines (Pinus peuce Griseb.), Pinus radiate D. Don, Pinus strobus L.) 360 and 230 base pairs in microbiota (Microbiota decussata Kom.), 230 and 200 base pairs in lilacs (Syringa komarowii CK Schneid and Syringa amurensis Rupr.).

To assess the intraspecific polymorphism of the rbcL gene, PCR-RFLP analysis of seven varieties of western thuja (Thuja occidentalis L.) was performed. Examples of electrophoretic separation of restriction fragments for thuja species and varieties are shown in Figure 2. When cleavage with restriction enzyme BstHHI in all thuja species and varieties, three DNA fragments were observed on the gel - 1000, 270 and $180 \mathrm{bp}$. When using the BstMBI enzyme, 3 DNA fragments were also detected in all species and varieties - 520, 450, and 400 nucleotide pairs. 


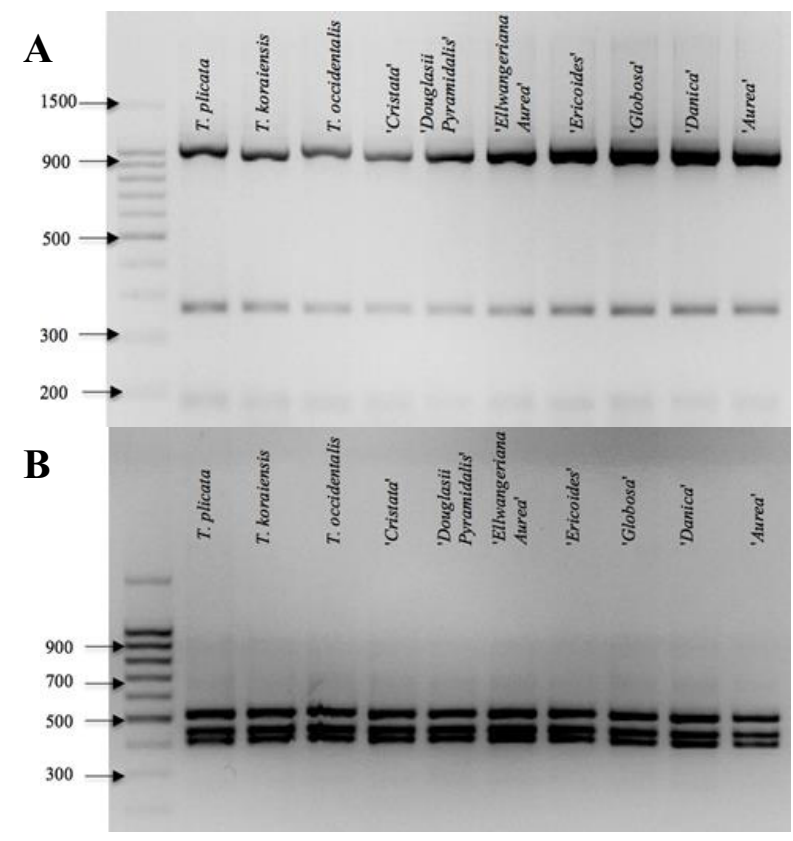

Fig 2. PCR-RFLP profiles of the rbcL gene of different species and varieties of thuja obtained using the enzymes BstHHI (A) and BstMBI (B).

When the PCR product was treated with the enzymes AluI, HpaII and BsuRI, an identical PCR-RFLP was also revealed for all species and varieties of thuja (Table 3). When the BsuRI enzyme was used for restriction, fragments of 450, 380, 290, and 180 base pairs in length were detected in all plants of the genus Thuja, fragments of AluI in length were 620,420 , and $250 \mathrm{bp}$, and for the HpaII enzyme, fragments in lengths of 320, 250, and $170 \mathrm{bp}$ were detected.

Table 3. Characterization of PCR-RFLP profiles of plants of the genus Thuja.

\begin{tabular}{cll}
\hline № $\mathbf{n} / \mathbf{I}$ & enzyme & $\begin{array}{c}\text { Length of detected restriction } \\
\text { fragments, nucleotide pairs }\end{array}$ \\
\hline 1 & BsuRI & $450,380,290,180$ \\
\hline 2 & AluI & $620,420,250$ \\
\hline 3 & HpaII & $320,250,170$ \\
\hline 4 & BstHHI & $1000,270,180$ \\
\hline 5 & BstMBI & $520,450,400$ \\
\hline
\end{tabular}

In general, the studies failed to identify unique PCR-RFLP markers characteristic of each species studied. Species belonging to the same genus in all cases had an identical restriction profile. In addition, for individual restriction endonucleases, there was also a coincidence of restriction profiles in species belonging to different genera of the Pinaceae family. Thus, identical PCR-RFLP profiles with the use of the HpaII and BstMBI enzymes were established for all spruces and firs, with the use of the BstHHI enzyme - for all pines and barely, with the use of the AluI enzyme - for all pines and firs. A comparative study of seven Western thuja cultivars showed the absence of rbcL gene polymorphism in the location of restriction sites of the restriction endonucleases selected for the study. 


\section{Discussion}

Thus, by the example of the assessment of species and varieties, it has been shown that the nucleotide sequences of the rbcL gene may not differ in the presence and presence of restriction sites for specific enzymes. The tested combination of enzymes made it possible to establish the variability of the rbcL gene only at the genus level. The studied species belonging to the same genus had an identical restriction profile. In addition, identical combinations of restriction DNA fragments were found for individual enzymes in species belonging to different genera. Thus, for the enzyme AluI, the same restriction profile was found in representatives of the genus Pinus and Abies, and for the enzyme BstHHI in Pinus and Picea species. All species belonging to the genera Abies and Picea were characterized by identical PCR-RFLP profiles obtained with HpaII and BstMBI enzymes. However, there is evidence in the literature that PCR-RFLP analysis using other combinations of restriction endonucleases still reveals interspecies and even intraspecific polymorphisms. Based on the analysis of five regions of cpDNA using a unique combination of restriction endonucleases for each region, 45 species of the Pinaceae family were identified [1]. On the other hand, a group of authors, examining the nucleotide sequences of seven chlDNA regions in six species of the genus Picea, came to the conclusion that none of them has sufficient resolution for spruces, although a combination of two loci can be used as a DNA barcode matK and rbcL [9]. When studying the nucleotide sequence of the rbcL gene in four Japanese species of the genus Abies, only one nucleotide substitution was found [10].

Due to the high conservatism, the intraspecific variability of chIDNA is more difficult to detect. For example, when analyzing the spacer region between tRNA genes in cpDNA, identical restriction profiles were obtained for all trees from seven populations from Greece and Italy [6]. However, in the scientific literature there are works that show the possibility of using PCR-RFLP analysis of chlDNA regions for detecting intraspecific variability. In particular, it was possible to identify intraspecific polymorphism of cpDNA regions (trnMrbcL and trnK1-trnK2) of one of the papaya species (Vasconcellea microcarpa (Jacq.) A.DC.) using 18 different restriction enzymes [3]. found in four (Abies alba Mill., Abies cephalonica var. cephalonica (Loudon) K. Richt., Abies concolor var. concolor (Gordon) Lindl. ex Hildebr., Abies numidica de Lannoy ex Carrière) [2]. it is necessary to continue the search for a combination of restriction endonucleases, which makes it possible to effectively mark both individual taxa (family, genus, species) and individual genotypes.

\section{Conclusion}

An intergeneric polymorphism of the rbcL gene nucleotide sequence was revealed based on the analysis of the frequency of restriction sites for five restriction endonucleases (AluI, HpaII, BsuRI, BstHHI, BstMBI). For all studied genera (Pinus sp., Abies sp., Picea sp., Microbiota sp., Syringa sp., Thuja sp.), A unique restriction profile was established. It was not possible to reveal polymorphism of the chloroplast rbcL gene at the interspecies and intraspecific levels using the listed enzymes. Species belonging to the same genus showed identical PCR-RFLP profiles. All varieties of thuja european also had an identical restriction profile for all enzymes used in the study. It is quite possible that further studies, with the inclusion of a larger number of tree species and enzymes, will reveal polymorphism at the intrageneric and intraspecific levels.

The research was supported by the Ministry of Science and Higher Education of the Russian Federation (Grant № 075-15-2021-674) and Core Facility Centre «Ecology, biotechnologies and processes for obtaining environmentally friendly energy carriers» of Volga State University of Technology, Yoshkar-Ola. 


\section{References}

1. Y. Tsumura, K. Yoshimura, N. Tomaru, K. Ohba, Theor. and App. Genetics, 91 (1995)

2. L. Parducci, A. E. Szmidt, Theor. and App. Genetics, 98 (1999)

3. B. Van Droogenbroeck, T. Kyndt, s I. Marten, E. Romeijn-Peeters, X. Scheldeman, J. P. Romero-Motochi, P. Van Damme, P. Goetghebeur, G. Gheysen, Theor. and App. Genetics, 108 (2004)

4. P. Taberlet, L. Gielly, G. Pautou, J. Bouvet, Plan Mol. Biol., 17 (1991)

5. B. Ziegenhagen, M. Fladung, Theor. and App. Genetics, 94 (1997)

6. G. Boscherini, M. Morgante, P. Rossi, G. Vendramin, Heredity, 73 (1994)

7. E. A. Kellogg, N. D. Juliano, Amer. J. of Bot., 84 (1997)

8. J. J. Doyle, J. L. Doyle, Phytochem. Bull., 19 (1987)

9. J. H. Ran, P. P. Wang, H. J. Zhao, X. Q. Wang, J. of Integr. Plant Biol., 52 (2010)

10. Y. Tsumura, Y. Suyama, Evol., 52 (1998) 